\title{
Effects of the aquarium fish industry in Costa Rica on populations of the Cortez rainbow wrasse Thalassoma lucasanum
}

\section{Efectos de la industria de peces ornamentales en Costa Rica sobre las poblaciones de la vieja de Cortés Thalassoma lucasanum}

\author{
DJ McCauley ${ }^{1}$, FJ Joyce², JH Lowenstein ${ }^{3,4}$ \\ ${ }^{1}$ Stanford University, Department of Biological Sciences, Stanford, CA 94305, USA. E-mail: dougm@stanford.edu \\ 2 Education Abroad Program, University of California, Monteverde, Apdo. 32-5655, Puntarenas, Costa Rica. \\ ${ }^{3}$ American Museum of Natural History, Department of Ichthyology, New York, NY 10024, USA. \\ ${ }^{4}$ Columbia University, E3B Department, New York, NY 10025, USA.
}

\begin{abstract}
Costa Rica hosts an active industry for the collection of marine ornamental reef fish that are supplied to the international aquarium fish trade. Little is known about the effects that collection activities may be having upon target species in Costa Rica, although research elsewhere gives reason for concern. Thalassoma lucasanum (Cortez rainbow wrasse) is an important species in this fishery. Costa Rican collectors prize the vibrantly colored terminal phase T. lucasanum individuals, but also collect the less dramatic initial phase T. lucasanum. We measured the density of T. lucasanum and the length of terminal phase individuals on highly collected reefs close to a fishing village and on nearby less-collected reefs located within the Guanacaste Conservation Area. Our findings show that densities of T. lucasanum were significantly lower and that terminal phase individuals were significantly smaller on the reefs near the fishing village where collection pressure was high. These findings indicate that even moderate amounts of relatively non-destructive aquarium fish extraction can negatively affect targeted populations. We present some suggestions for the reform of the aquarium reef fish industry in Costa Rica, which we believe would improve the long-term sustainability of this fishery.
\end{abstract}

Key words: aquarium fish, conservation, Costa Rica, marine protected area, ornamental fish.

\section{Resumen}

En Costa Rica la extracción de peces ornamentales de arrecife, para abastecer el mercado internacional, es una industria importante. Se sabe poco acerca del efecto de esta extracción sobre las especies explotadas en Costa Rica, pero investigaciones realizadas en otros sitios sugieren que puede tener un impacto negativo. Thalassoma lucasanum (vieja de Cortés) es importante para esta actividad. Los vibrantes colores que presentan los individuos de T. lucasanum en su fase terminal los hace muy apreciados, aunque también se recolectan individuos en su fase inicial menos atractiva. Se compararon la densidad de las poblaciones de T. lucasanum y la longitud de sus individuos en fase terminal, en arrecifes cercanos a una comunidad de pescadores, donde se realiza una extracción intensiva, y en arrecifes adyacentes dentro del Área de Conservación Guanacaste, donde la explotación es limitada. La densidad de T. lucasanum fue significativamente menor y los individuos en fase terminal presentaron talla menor en los arrecifes donde la presión de extracción es más intensa. Estos resultados indican que aun la extracción relativamente no destructiva de peces ornamentales, en cantidades moderadas, puede afectar negativamente las poblaciones objetivo. Se sugieren algunas modificaciones a los métodos de explotación de estas especies en Costa Rica que podrían conducir hacia la sustentabilidad de la actividad en el largo plazo.

Palabras clave: áreas marinas protegidas, conservación, Costa Rica, peces de acuario, peces ornamentales.

\section{Introduction}

Past research has demonstrated that the collection of marine ornamental reef fish for the aquarium fish trade can have detrimental effects upon targeted populations (Lubbock and Polunin 1975, Edwards and Shepherd 1992, Wood 2001, Sadovy and Vincent 2002, Kolm and Berglund 2003, Tissot and Hallacher 2003, Shuman et al. 2005, Jones et al. 2008). In Costa Rica, approximately 40 species of marine fishes are taken by the aquarium fish industry, which has been regionally

\section{Introducción}

En estudios anteriores se ha demostrado que la extracción de peces ornamentales de arrecifes para abastecer el mercado internacional puede resultar en detrimento de las poblaciones explotadas (Lubbock y Polunin 1975, Edwards y Shepherd 1992, Wood 2001, Sadovy y Vincent 2002, Kolm y Berglund 2003, Tissot y Hallacher 2003, Shuman et al. 2005, Jones et al. 2008). En Costa Rica se capturan aproximadamente 40 especies ícticas por la industria de peces ornamentales, la cual ha 
active for approximately 20 years (Gutiérrez 2005). Fish are wild captured from reefs by divers using hand nets; however, there is very little information on the impact that collection activities in Costa Rica may be having on targeted fish stocks and associated reef communities (Dominici-Arosemena 1999, Gutiérrez 2005).

We studied the potential effects of ornamental fish collection in northwest Costa Rica on a single species, Thalassoma lucasanum (Gill 1862), the Cortez rainbow wrasse. The species is protogynous hermaphroditic and displays color dimorphism (Warner 1982). The largest fish exhibit terminal phase (TP) coloration, while the initial phase (IP) coloration is maintained by all other members of the population (Warner and Robertson 1978, Warner 1982). The brighter coloration of TP individuals makes them more attractive to aquarium keepers and they are therefore prized by collectors. One of the top three most important fish involved in the Costa Rican aquarium fish industry is TP T. lucasanum (Gutiérrez 2005); IP individuals are also in demand, though they bring lower prices. At present, $T$. lucasanum has no commercial value except in the aquarium trade. We selected this species for study because it is one of the most commonly collected ornamental fish in this area. Trends observed in its response to collecting pressure should help provide insight about the impact of this fishery on other more rare and difficult to survey target species.

During this study, we compared populations of $T$. lucasanum on reefs receiving high collection pressure (situated near a fishing community) to populations on more inaccessible reefs receiving low collection pressure. Our aim was to assess the impact of collection pressure on IP and TP T. lucasanum density and TP T. lucasanum size.

\section{Material and methods}

We conducted this research from September 2000 to January 2001 in the Guanacaste Province of Costa Rica. Two sites were selected that differed from each other with respect to intensity of fishing collection pressure. The first, termed the high collection pressure (HCP) site, was situated along the Santa Elena Peninsula approximately $9 \mathrm{~km}$ from the fishing community of Cuajiniquil $\left(10^{\circ} 56.49^{\prime \prime} \mathrm{N}, 85^{\circ} 42.05^{\prime \prime} \mathrm{W}\right)$. The second, termed the low collection pressure (LCP) site, was located at the Murciélago Island Archipelago within the boundaries of the marine sector of the Guanacaste Conservation Area, approximately $40 \mathrm{~km}$ by boat from Cuajiniquil $\left(10^{\circ} 51.15^{\prime} \mathrm{N}, 8^{\circ} 54.47^{\prime} \mathrm{W}\right)$. Based on interviews with collectors, conservation area managers, and personal observations, we estimated that the general HCP region was fished approximately 216 days a year, whereas the general LCP region was fished only 23 days per year (days/year = average number of boats collecting/day $\times$ average number of days individual fisherman collect/year). At the time of this study there was no patrol in effect to prevent fishing in the conservation area at the LCP site, and the lower fishing pressure here is mostly a result of the greater distance and higher costs of travel to this site. operado activamente en la región desde hace aproximadamente 20 años (Gutiérrez 2005). Los peces silvestres de arrecifes son capturados por buzos con redes de mano; sin embargo, existe muy poca información sobre el impacto que podría estar teniendo esta captura sobre las especies objetivo y las comunidades arrecifales asociadas de Costa Rica (DominiciArosemena 1999, Gutiérrez 2005).

En este trabajo se estudiaron los efectos potenciales de la extracción de peces ornamentales en el noroeste de Costa Rica sobre una especie objetivo, la vieja de Cortés Thalassoma lucasanum (Gill 1862). Esta especie hermafrodita protoginea muestra dimorfismo cromático (Warner 1982). Los individuos de mayor tamaño presentan una coloración típica de su fase terminal (FT), mientras que los demás miembros de la población mantienen la coloración típica de la fase inicial (FI) (Warner y Robertson 1978, Warner 1982). Los colores brillantes de los individuos en FT los hace más atractivos para los acuarios y, por tanto, son altamente valorados por los coleccionistas. Thalassoma lucasanum en FT es una de las tres especies más importantes en la industria de peces ornamentales de Costa Rica (Gutiérrez 2005), y aunque también hay demanda para individuos en FI, éstos tienen menor precio. Actualmente T. lucasanum no tiene valor comercial más que para la industria de peces ornamentales y fue seleccionada para este estudio por ser una de las especies más capturadas para este fin. Sus patrones de respuesta a la presión de pesca podrían proporcionar información sobre el impacto de esta pesquería sobre otras especies objetivo menos comunes y más difíciles de estudiar.

Durante este estudio se compararon las poblaciones de $T$. lucasanum de arrecifes sujetos a una intensa presión de extracción (localizados cerca de una comunidad pesquera) con las de arrecifes menos accesibles, sujetas a poca presión. El objetivo fue evaluar el impacto de la presión de captura sobre la densidad de individuos de T. lucasanum en FT y FI y sobre el tamaño de T. lucasanum en FT.

\section{Materiales y métodos}

Esta investigación se realizó de septiembre de 2000 a enero de 2001 en la provincia de Guanacaste, Costa Rica. Se seleccionaron dos sitios que difirieron en cuanto a la intensidad de la presión por pesca. El primero, que se denominó sitio de alta presión de captura (APC), se localiza en la península de Santa Elena, aproximadamente a $9 \mathrm{~km}$ de la comunidad pesquera de Cuajiniquil $\left(10^{\circ} 56.49^{\prime} \mathrm{N}, 8^{\circ} 42.05^{\prime}\right.$ O). El segundo, un sitio de baja presión de captura (BPC), se localiza en el Archipiélago de las islas Murciélago, dentro de los confines del sector marino del Área de Conservación Guanacaste, alrededor de $40 \mathrm{~km}$ de Cuajiniquil (1051.15” N, 8554.47” O), accesible por barco. Con base en entrevistas a pescadores, administradores del área de conservación y observaciones personales, se estimó que en la región general de APC se pesca durante 216 días al año, mientras que en la región general de BPC sólo se pesca 23 días al año (días/año = promedio de barcos que capturan por día $\times$ promedio de días en que capturan 
Within LCP and HCP sites, two reefs of different depth categories were selected for sampling: a shallow reef with a mean depth of $6.2 \mathrm{~m}$ and a deep reef of $10.0 \mathrm{~m}$ mean depth. Sampling was conducted using SCUBA and a stationary visual census technique adopted from Bohnsack and Bannerot (1986) and Dominici-Arosemena (1999). A survey location at each reef was selected at random. After descending to the bottom at this location, we extended a 6-m cord that became the radius of an imaginary cylindrical observational arena extending from the bottom to the surface. On occasion, the size of the cylinder was reduced because visibility was less than $6 \mathrm{~m}$. In such instances, visibility was measured by the observer. Four replicate censuses were conducted during each visitation to the shallow reef and three replicates were conducted during each visitation to the deep reef. Each replicate census was made at different, haphazardly chosen portions of each reef. During each census, the number of T. lucasanum displaying IP and TP coloration and the total lengths of all TP individuals were estimated within the observation arena over the course of $10 \mathrm{~min}$. Transitional phase individuals (morphologically between IP and TP) were classed as TP. As a control, we also recorded the number of common pomacentrid Chromis atrilobata during a subset (39 of 75) of the censuses. This species has no value in the aquarium industry and is not collected by fisherman at these sites. Thus, we hypothesized that its densities should not vary between HCP and LCP sites and would provide a control for our comparisons of harvested T. lucasanum. All observations were made by the same observer (DJM). Accuracy of fish length approximations was tested using models of known size and estimation error was found to be less than 10\%. During each observation, we sketched the composition of the substrate contained within the sampling area using the following six categories: Pocillopora sp. coral, Pavona sp. coral, massive rock ( $>10 \mathrm{~kg})$, fragmented rock ( $<10 \mathrm{~kg})$, sand, and mixed sand and rubble. Depth and temperature data were also recorded using digital sensors carried by the observer. Sites were surveyed once every two to three weeks, producing a total of 35 censuses at HCP sites and 40 at LCP sites. Surveys in HCP and LCP regions were conducted no more than one day apart, with the exception of the observations on 26 November 2000 (two days apart). All data were taken from the different reefs of each site within a 5-h period, except for observations made on 23 September 2000 (24 h apart). Observations were consistently made in the morning and early afternoon.

Due to small sample size, the data from the shallow and deep reefs within each site were pooled for statistical analysis. Densities of IP and TP T. lucasanum and C. atrilobata were obtained by dividing the observed number of individuals by the basal area of each respective observation cylinder (in the cases where the visibility was less than $6 \mathrm{~m}$, the basal area was adjusted to the measured limits of ambient visibility). The percent substrate cover was estimated from sketches. A Wilcoxon rank sum test was used to compare the densities of IP and TP T. lucasanum and C. atrilobata at HCP and LCP sites, while a two-tailed Student's $t$-test was used to compare los pescadores individuales por año). Mientras se realizaba este estudio no hubo patrullaje que impidiera la pesca en el área de conservación de BPC, y la menor presión de pesca se debía más bien a su mayor lejanía y los mayores costos de traslado a ese sitio.

Dentro de los sitios de BPC y APC se seleccionaron para su estudio dos arrecifes de diferentes categorías de profundidad, uno somero con una profundidad media de $6.2 \mathrm{~m}$ y uno profundo de $10.0 \mathrm{~m}$ de profundidad media. Los muestreos se realizaron con equipo de buceo autónomo y empleando una técnica de censo visual estacionario tomada de Bohnsack y Bannerot (1986) y Dominici-Arosemena (1999). En cada arrecife se seleccionó al azar una zona de observación en cuyo fondo se extendió una cuerda de $6 \mathrm{~m}$ que representaba el radio de un cilindro imaginario de observación que se extendía desde el fondo hasta la superficie. En ocasiones, cuando la visibilidad era menor a $6 \mathrm{~m}$, se redujo el tamaño del cilindro. En esos casos la visibilidad fue medida por el observador. Se realizaron cuatro réplicas de censo durante cada visita al arrecife somero y tres réplicas durante cada visita al profundo. Cada réplica de censo se realizó en diferentes porciones escogidas aleatoriamente en cada arrecife. Durante cada censo se estimó, a lo largo de $10 \mathrm{~min}$, el número de individuos de T. lucasanum que mostraban las coloraciones típicas de FI y de FT, así como la longitud media de todos los individuos en FT dentro de la zona de observación. Los individuos en fase transicional (morfológicamente entre FI y FT) fueron clasificados como FT. Como control también se registró el número de individuos de Chromis atrilobata (Pomacentridae) en una submuestra (39 de $75)$ de los censos. Dado que esta última especie no tiene ningún valor para la industria de peces de acuario y no se captura en estos sitios, se planteó la hipótesis de que sus densidades no deberían de variar entre los sitios de APC y BPC, por lo que serviría de control para compararla con T. lucasanum. Todas las observaciones se llevaron a cabo por el mismo observador (DJM). Se probó la precisión de las aproximaciones de la longitud de los peces mediante modelos de tamaño conocido y el error de estimación resultó menor al 10\%. Durante cada observación se esquematizó la composición del sustrato dentro de la zona de muestreo usando las siguientes seis categorías: coral Pocillopora sp., coral Pavona sp., roca masiva (>10 kg), roca fragmentada ( $<10 \mathrm{~kg}$ ), arena, y arena mixta y grava. También se registraron la profundidad y la temperatura usando sensores digitales que portaba el observador. Los sitios fueron muestreados cada dos a tres semanas, para un total de 35 censos en el sitio de APC y 40 en el de BPC. Los muestreos en ambos sitios se realizaron con un día o menos de separación, con excepción de los del 26 de noviembre de 2000 (dos días). Todos los datos se tomaron de los diferentes arrecifes de cada sitio dentro de un periodo de $5 \mathrm{~h}$, excepto en el caso de las observaciones del 23 de septiembre de 2000 (24 h). Las observaciones consistentemente se llevaron a cabo en la mañana y temprano por la tarde.

Debido al reducido tamaño de la muestra, los datos de los arrecifes someros y profundos de cada sitio se unieron para el análisis estadístico. Las densidades de T. lucasanum en FI y FT 
the lengths of TP individuals. We compared percent cover of each of the six substrate types and temperature between LCP and HCP sites using Wilcoxon rank sum tests. A stepwise screening procedure was used to determine which of the eight measured habitat variables (including the six substrate types, temperature, and fishing pressure) best explained the variation in IP and TP density and TP length. Selected variables were then used to model a least squares multiple regression. All statistics were computed using program $\mathrm{R}$ version 2.1.1 (R Foundation for Statistical Computing, Vienna, Austria; http:www.Rproject.org) and JMP version 5.1 (SAS Institute Inc., Cary, NC, USA).

\section{Results}

\section{Density}

Both phases of $T$. lucasanum were significantly more abundant on LCP than HCP reefs. There were approximately six times more IP T. lucasanum on LCP reefs (mean 0.18 ind $\mathrm{m}^{-2}$, $\mathrm{SD} \pm 0.22$ ) than on HCP reefs (mean 0.03 ind $\mathrm{m}^{-2}, \mathrm{SD} \pm 0.04$ ) ( $W=1126, P<0.0001)$. There were approximately 2.5 times more TP T. lucasanum on LCP reefs (mean 0.01 ind $\mathrm{m}^{-2}, \mathrm{SD} \pm$ 0.02 ) than on HCP reefs (mean 0.004 ind $\mathrm{m}^{-2}, \mathrm{SD} \pm 0.008$ ) $(W=1000, P<0.001)$. However, densities of non-target control fish C. atrilobata were relatively equal between LCP (mean 0.3 ind $\mathrm{m}^{-2}, \mathrm{SD} \pm 0.3$ ) and HCP reefs (mean 0.2 ind $\mathrm{m}^{-2}$, $\mathrm{SD} \pm 0.3)(W=230, P=0.26)$.

\section{Length}

The TP T. lucasanum individuals on LCP reefs (mean $9.5 \mathrm{~cm}, \mathrm{SD} \pm 3.6$ ) were significantly larger-almost twice as large - as fish on HCP reefs (mean $4.8 \mathrm{~cm}, \mathrm{SD} \pm 0.7)(T=9.3$, d.f. $=69, P<0.0001)$.

\section{Habitat characteristics}

Densities of massive rock, fragmented rock, Pocillopora coral, and temperature were significantly different between LCP and HCP sites (table 1). The variation in IP density was best explained by fishing pressure, temperature, and percent cover of Pavona coral; the variation in TP density was best explained by fishing pressure, percent cover of Pavona coral, and massive rock; and the variation in TP length was best explained by fishing pressure, temperature, and percent cover of Pocillopora coral (table 2).

\section{Discussion}

Both phases of $T$. lucasanum were more abundant and TP $T$. lucasanum were larger at LCP sites as compared with HCP sites. Densities of the control fish C. atrilobata, however, remained similar between sites. Substrate type, coral cover, productivity, and temperature can affect the abundance and growth rates of fishes (Luckhurst and Luckhurst 1978, Bell and y de C. atrilobata se obtuvieron dividiendo el número de individuos observados entre el área basal de cada cilindro de observación respectivo (cuando la visibilidad fue menor a $6 \mathrm{~m}$, el área basal se ajustó a los límites de visibilidad ambiental medidos). El porcentaje de cobertura del sustrato se estimó a partir de los esquemas. Se empleó la prueba de la suma de rangos de Wilcoxon para comparar las densidades de T. lucasanum en FI y FT y de C. atrilobata en los sitios de APC y BPC, y se utilizó la prueba $t$ de Student de dos colas para comparar la longitud de los individuos en FT. Se comparó el porcentaje de cobertura de cada uno de los seis tipos de sustrato y la temperatura entre los sitios de APC y BPC usando la prueba de la suma de rangos de Wilcoxon. Se utilizó un procedimiento de evaluación escalonada para determinar cuáles de las ocho variables ambientales medidas (i.e., los seis tipos de sustratos, la temperatura y la presión de pesca) explicaban mejor la variación en la densidad de individuos en FI y FT y en la longitud de individuos en FT. Posteriormente se usaron variables seleccionadas para modelar una regresión múltiple por cuadrados mínimos. Todos los análisis estadísticos se realizaron con el programa $\mathrm{R}$ versión 2.1.1 (R Foundation for Statistical Computing, Viena, Austria; http:www.Rproject.org) y el programa JMP versión 5.1 (SAS Institute Inc., Cary, NC, EUA).

\section{Resultados}

\section{Densidad}

Ambas fases de T. lucasanum fueron significativamente más abundantes en los arrecifes de BPC que en los de APC. Se observaron aproximadamente seis veces más individuos de $T$. lucasanum en FI en los arrecifes de BPC (media 0.18 ind $\mathrm{m}^{-2}$, $\mathrm{DE} \pm 0.22$ ) que en los de APC (media 0.03 ind $\mathrm{m}^{-2}, \mathrm{DE} \pm 0.04$ ) $(W=1126, P<0.0001)$. Se observaron aproximadamente 2.5 veces más individuos de $T$. lucasanum en FT en los arrecifes de BPC (media 0.01 ind $\mathrm{m}^{-2}$, $\mathrm{DE} \pm 0.02$ ) que en los de APC (media 0.004 ind $\left.\mathrm{m}^{-2}, \mathrm{DE} \pm 0.008\right)(W=1000, P<0.001)$. Sin embargo, las densidades del pez control C. atrilobata fueron relativamente iguales en los arrecifes de BPC (media 0.3 ind $\mathrm{m}^{-2}, \mathrm{DE} \pm 0.3$ ) y APC (media 0.2 ind $\mathrm{m}^{-2}, \mathrm{DE} \pm 0.3$ ) $(W=230, P=0.26)$.

\section{Longitud}

Los individuos de T. lucasanum en FT de los arrecifes de BPC (media $9.5 \mathrm{~cm}, \mathrm{DE} \pm 3.6$ ) fueron significativamente más grandes—casi dos veces más—que los de APC (media $4.8 \mathrm{~cm}$, $\mathrm{DE} \pm 0.7)(T=9.3$, g.l. $=69, P<0.0001)$.

\section{Características del hábitat}

Las densidades de roca masiva, roca fragmentada, coral Pocillopora y temperatura fueron significativamente diferentes entre los sitios de BPC y APC (tabla 1). La variación en la densidad de peces en FI fue mejor explicada por la presión de pesca, la temperatura y el porcentaje de cobertura del coral 
Table 1. Wilcoxon rank sum test comparisons of temperature and substrate type between sites of low collection pressure (LCP) and high collection pressure (HCP). Values reported are means (temperature in ${ }^{\circ} \mathrm{C}$ and substrate type as percent bottom cover in observation area $( \pm S D)$ ).

Tabla 1. Comparaciones de la prueba de suma de rangos de Wilcoxon de la temperatura y el tipo de sustrato entre los sitios con baja presión de captura (LCP) y alta presión de captura (HCP). Los valores son promedios (la temperatura se da en ${ }^{\circ} \mathrm{C}$ y el tipo de sustrato como porcentaje de la cobertura en la zona de observación ( $\left.\pm \mathrm{SD}\right)$ ).

\begin{tabular}{lcccc}
\hline Parameter & LCP & HCP & $W$ & $P$ \\
\hline Temperature* & $25.5( \pm 1.3)$ & $24.4( \pm 1.1)$ & $W=1131$ & $<0.0001$ \\
Massive rock* & $62.5( \pm 15.1)$ & $44.1( \pm 29.5)$ & $W=951$ & $<0.01$ \\
Pocillopora* & $6.4( \pm 4.5)$ & $1.8( \pm 3.2)$ & $W=1089$ & $<0.0001$ \\
Pavona & $3.9( \pm 5.4)$ & $4.3( \pm 4.5)$ & $W=581$ & 0.24 \\
Fragmented rock* & $5.3( \pm 8.4)$ & $20.8( \pm 25.1)$ & $W=484$ & 0.014 \\
Sand & $8.7( \pm 9.3)$ & $10.1( \pm 11.3)$ & $W=699$ & 0.99 \\
Sand and rubble & $13.1( \pm 11.6)$ & $18.9( \pm 17.5)$ & $W=565$ & 0.15 \\
\hline
\end{tabular}

*Significant

Galzin 1984, Williams 1991, Sogard and Olla 2001), although Giraldo et al. (2001) found that these features may not be of primary importance for T. lucasanum (at least in regard to fish abundance). The HCP and LCP sites did differ significantly in some of these characteristics (table 1). Results from multiple regressions suggest that some of these other factors (notably temperature and percent coral cover) may be playing a role in determining the local abundance of $T$. lucasanum and the size of TP T. lucasanum individuals (table 2). However, in our analysis, fishing pressure consistently explained the greatest amount of variance for both T. lucasanum density and TP length (table 2). We therefore suggest that fishing pressure in this area of Costa Rica is having an important impact on the abundance and size of $T$. lucasanum.

Results from this study are consistent with the results from other research on T. lucasanum conducted on similar HCP and LCP reefs at this site during different years and in different seasons. In November 2002, Lowenstein (unpub. manuscript) found that $T$. lucasanum density increased with distance from the HCP fishing community of Cuajiniquil. Similarly, in May 2008 Cannon (unpub. mansucript) found that TP T. lucasanum was significantly more abundant in LCP than HCP sites. The congruence between their findings and ours suggests that the impacts of the aquarium fish trade on $T$. lucasanum are robust and persist through time; however, longer-term surveys should be instituted on a regular basis to carefully monitor these impacts.

Thalassoma lucasanum is a relatively prolific species and we do not intend to suggest that it is in danger of local extirpation in Costa Rica. Nevertheless, densities of other fish species harvested by ornamental collectors in these same localities are much lower than $T$. lucasanum and these stocks may be at risk of overexploitation. Declines in aquarium fish landings are already evident for certain species in this region (Gutiérrez 2005). Furthermore, the impact of this fishery cannot be considered to be affecting only the fish species that are being
Pavona; la variación en la densidad de individuos en FT fue mejor explicada por la presión de pesca, el porcentaje de cobertura de coral Pavona y roca masiva; y la variación en la longitud en FT lo fue por la presión de pesca, la temperatura y el porcentaje de cobertura de Pocillopora (tabla 2).

\section{Discusión}

Ambas fases de T. lucasanum fueron más abundantes y sus individuos en FT más grandes en el sitio de BPC que en el de APC; sin embargo, las densidades del pez control C. atrilobata resultaron similares entre todos los sitios. El tipo de sustrato, la cobertura de coral, la productividad y la temperatura pueden afectar la abundancia y las tasas de crecimiento de los peces (Luckhurst y Luckhurst 1978, Bell y Galzin 1984, Williams 1991, Sogard y Olla 2001), aunque Giraldo et al. (2001) encontraron que estos factores podrían no ser muy importantes para T. lucasanum (por lo menos en cuanto a su abundancia). Los sitios de APC y BPC sí mostraron diferencias significativas en algunas de estas características (tabla 1). Los resultados de las regresiones múltiples sugieren que algunos de estos factores (en particular la temperatura y el porcentaje de cobertura de coral) pueden estar jugando un papel en la determinación de la abundancia local de $T$. lucasanum y el tamaño de sus individuos en FT (tabla 2). Sin embargo, en nuestro análisis la presión de pesca explicó de manera consistente la mayor parte de la variación de la densidad de T. lucasanum, así como de la longitud de sus individuos en FT (tabla 2). Por tanto, se sugiere que la presión de pesca en esta región de Costa Rica está impactando significativamente tanto la abundancia como el tamaño de $T$. lucasanum.

Los resultados de este trabajo coinciden con los de otros estudios sobre $T$. lucasanum realizados en arrecifes similares de la zona en diferentes años y temporadas. En noviembre de 2002, Lowenstein (datos no publicados) encontró que la densidad de $T$. lucasanum aumentaba con la distancia a la 
Table 2. Multiple regression of Thalassoma lucasanum initial phase (IP) and terminal phase (TP) density (indivduals $\mathrm{m}^{-2}$ ) and terminal phase total length $(\mathrm{cm})$ with substrate types, temperature, and fishing pressure. The independent variables identified in each regression were selected using a stepwise screening procedure.

Tabla 2. Regresión múltiple de la densidad deThalassoma lucasanum en fase inicial (IP) y fase terminal (TP) (individuos $\mathrm{m}^{-2}$ ) y de la longitud total de organismos en fase terminal $(\mathrm{cm})$ con los tipos de sustrato, la temperatura y la presión de pesca. Las variables independientes identificadas en cada regresión se seleccionaron usando un procedimiento de evaluación escalonada.

\begin{tabular}{lccc}
\hline Parameter & $R^{2}$ & $F$ & $P$ \\
\hline IP density & 0.30 & 9.9 & $<0.0001$ \\
Fishing pressure* & & 21.0 & $<0.0001$ \\
Temperature & & 3.8 & 0.06 \\
Pavona* & & 8.5 & $<0.01$ \\
TP density & 0.22 & 6.7 & $<0.001$ \\
Fishing pressure* & & 16.7 & $<0.001$ \\
Pavona* $_{\text {Massive rock }}$ & 4.0 & 0.05 \\
TP length & & 3.7 & 0.06 \\
Fishing pressure* & & 17.8 & $<0.0001$ \\
Temperature* & & 26.4 & $<0.0001$ \\
Pocillopora* $^{*}$ & & 5.0 & 0.03 \\
\hline
\end{tabular}

*Significant

harvested. Because reductions in certain species and groups of species can cause widespread cascading changes in marine ecosystems (Dulvy et al. 2004), we should expect that the removal of the fish targeted in the aquarium fish trade can have impacts on other marine taxa and ecosystem functions.

Countries such as Costa Rica have already taken some important first steps towards managing aquarium fish harvest, primarily by means of explicit licensing procedures and harvest quotas (Gutiérrez 2005). Other measures available to further minimize the negative ecological impact of ornamental fisheries include: (a) establishing comprehensive wellmanaged marine protected areas, (b) institutionalizing industry reform to reduce fish mortality in transport from field to distributors, (c) developing aquaculture programs to support or bypass wild harvest, and (d) implementing "green fish" certification programs (e.g., Marine Aquarium Council; www.aquariumcouncil.org) (Edwards and Shepherd 1992, Adam 1995, Friedlander 2001, Ogawa and Brown 2001, Wood 2001, Lunn and Moreau 2004, Shuman et al. 2004, Calado 2006, Lecchini et al. 2006). Putting into practice some combination of these reform measures could help fishermen and resource managers guard against the overexploitation of aquarium fish stocks in Costa Rica and elsewhere.

\section{Acknowledgements}

We thank the staff of the Guanacaste Conservation Area and Instituto Costarricense de Pesca y Acuicultura comunidad pesquera de Cuajiniquil. Asimismo, en mayo de 2008, Cannon (datos no publicados) encontró que los individuos de T. lucasanum en FT eran significativamente más abundantes en los sitios de BPC que en los de APC. La congruencia entre sus resultados y los nuestros sugiere que los efectos de la industria de peces ornamentales sobre $T$. lucasanum son fuertes y persistentes en el tiempo; sin embargo, es necesario realizar estudios regulares de más largo plazo para monitorear estos impactos con cuidado.

Thalassoma lucasanum es una especie relativamente prolífica y no se pretende aquí sugerir que se encuentra en peligro de extinción local en Costa Rica. No obstante, las densidades de otras especies capturadas por la industria de peces ornamentales en estos mismos sitios son mucho menores y sus poblaciones podrían estar en peligro de sobreexplotación. En el caso de ciertas especies de peces para acuarios de esta región ya es evidente una reducción en sus capturas (Gutiérrez 2005). Además, el impacto de esta pesquería no sólo está afectando las especies de peces capturadas. Considerando que la reducción de ciertas especies y grupos de especies puede causar extensos cambios interrelacionados en los ecosistemas marinos (Dulvy et al. 2004), es de esperarse que la extracción de peces explotados para abastecer acuarios puede tener consecuencias sobre otros taxones marinos y funciones del ecosistema.

Países como Costa Rica ya han dado sus primeros pasos importantes hacia el manejo de la captura de peces ornamentales, principalmente mediante cuotas y procedimientos de permisos explícitos (Gutiérrez 2005). Otras medidas disponibles para minimizar el impacto ecológico negativo de pesquerías ornamentales incluyen: (a) establecer zonas marinas protegidas bien administradas, (b) institucionalizar reformas a la industria para reducir la mortandad de peces durante su transporte del campo a los distribuidores, (c) desarrollar programas de acuicultura para apoyar o evitar la pesca silvestre, y (d) implementar programas de certificación ecológica (e.g., Consejo de Acuarios Marinos; www.aquariumcouncil.org) (Edwards y Shepherd 1992, Adam 1995, Friedlander 2001, Ogawa y Brown 2001, Wood 2001, Lunn y Moreau 2004, Shuman et al. 2004, Calado 2006, Lecchini et al. 2006). El poner en práctica alguna combinación de estas medidas podría ayudar a los pescadores y a los administradores de los recursos a proteger las poblaciones de peces ornamentales de Costa Rica y otros países contra la sobreexplotación.

\section{Agradecimientos}

Se agradece al personal del Área de Conservación Guanacaste y del Instituto Costarricense de Pesca y Acuicultura (INCOPESCA) su cooperación y asistencia durante este estudio. P Ajtai, G Bassey, R Blanco, R Caldwell, L MayCollado, S Emerson, M Lara, J Ranganathan y E (Samba) Sequeira aportaron consejos valiosos y/o apoyo en el campo, y A Cannon compartió sus datos no publicados. Se agradece a R Chaves-Ulloa la traducción del resumen.

Traducido al español por Christine Harris. 
(INCOPESCA) for their cooperation and assistance in the conduct of this research. P Ajtai, G Bassey, R Blanco, R Caldwell, L May-Collado, S Emerson, M Lara, J Ranganathan, and E (Samba) Sequeira provided valuable advice and/or field assistance, and A Cannon shared unpublished data. We thank $\mathrm{R}$ Chaves-Ulloa for translation assistance.

\section{References}

Adam MS. 1995. Review of the aquarium fish trade for the Maldives. Ministry of Fisheries and Agriculture, Malé, Republic of Maldives, 29 pp.

Bell JD, Galzin R. 1984. Influence of live coral cover on coral-reef fish communities. Mar. Ecol. Prog. Ser. 15: 265-274.

Bohnsack JA, Bannerot SP. 1986. A stationary visual census technique for quantitatively assessing community structure of coral reef fishes. NOAA Technical Report NMFS 41, National Oceanic and Atmospheric Administration, Southeast Science Fisheries Center, Miami, USA, 15 pp.

Calado R. 2006. Marine ornamental species from European waters: A valuable overlooked resource or a future threat for the conservation of marine ecosystems? Sci. Mar. 70: 389-398.

Dominici-Arosemena A. 1999. Estructura poblacional de los peces de arrecifes del Golfo de Papagayo, Guanacaste, Costa Rica, con énfasis en las especies de mayor importancia comercial como ornamentales. M.Sc. thesis, Escuela de Biología, Universidad de Costa Rica, 208 pp.

Dulvy NK, Freckleton RP, Polunin NVC. 2004. Coral reef cascades and the indirect effects of predator removal by exploitation. Ecol. Lett. 7: 410-416.

Edwards AJ, Shepherd AD. 1992. Environmental implications of aquarium-fish collection in the Maldives, with proposals for regulation. Environ. Conserv. 19: 61-72.

Friedlander AM. 2001. Essential fish habitat and the effective design of marine reserves: Application for marine ornamental fishes. Aquarium Sci. Conserv. 3: 135-150.

Giraldo A, Gomez C, Ospina F. 2001. Abundance and spatial distribution of Thalassoma lucasanum (Gill, 1863) in a coral reef of the tropical eastern pacific. Bull. Mar. Sci. 68: 147-152.

Gutiérrez R. 2005. Peces ornamentales marinos: Una pesquería que debe modificarse. Instituto Costarricense de Pesca y Acuicultura, Guanacaste, Costa Rica. 23 pp.

Jones AM, Gardner S, Sinclair W. 2008. Losing “Nemo”: Bleaching and collection appear to reduce inshore populations of anemonefishes. J. Fish Biol. 73: 753-761.
Kolm N, Berglund A. 2003. Wild populations of a reef fish suffer from the "nondestructive" aquarium trade fishery. Conserv. Biol. 17: 910-914.

Lecchini D, Polti S, Nakamura Y, Mosconi P, Tsuchiya M, Remoissenet G, Planes S. 2006. New perspectives on the aquarium fish trade. Fish. Sci. 72: 40-47.

Lubbock HR, Polunin NVC. 1975. Conservation and the tropical marine aquarium trade. Environ. Conserv. 2: 229-232.

Luckhurst BE, Luckhurst K. 1978. Analysis of the influence of substrate variables on coral fish communities. Mar. Biol. 49: 317-324.

Lunn KE, Moreau MA. 2004. Unmonitored trade in marine ornamental fishes: The case of Indonesia's Banggai cardinalfish (Pterapogon kauderni). Coral Reefs 23: 344-351.

Ogawa T, Brown CL. 2001. Ornamental reef fish aquaculture and collection in Hawaii. Aquarium Sci. Conserv. 3: 151-169.

Sadovy YJ, Vincent ACJ. 2002. Ecological issues and the trade of live reef fishes. In: Sale PF (ed.), Coral Reef Fishes: Dynamics and Diversity in a Complex Ecosystem. Academic Press, San Diego, California, pp. 391-420.

Shuman CS, Hodgson G, Ambrose RF. 2004. Managing the marine aquarium trade: Is eco-certification the answer? Environ. Conserv. 31: 339-348.

Shuman CS, Hodgson G, Ambrose RF. 2005. Population impacts of collecting sea anemones and anemonefish for the marine aquarium trade in the Philippines. Coral Reefs 24: 564-573.

Sogard SM, Olla BL. 2001. Growth and behavioral responses to elevated temperatures by juvenile sablefish Anoplopoma fimbria and the interactive role of food availability. Mar. Ecol. Prog. Ser. 217: $121-134$.

Tissot BN, Hallacher LE. 2003. Effects of aquarium collectors on coral reef fishes in Kona, Hawaii. Conserv. Biol. 17: 1759-1768.

Warner RR. 1982. Mating systems, sex change and sexual demography in the rainbow wrasse, Thalassoma lucasanum. Copeia 1982: 653-661.

Warner RR, Robertson DR. 1978. Sexual patterns in the labroid fishes of the western Caribbean. I. The wrasses (Labridae). Smithson. Contrib. Zool. 254: 1-27.

Williams DM. 1991. Patterns and processes in the distribution of coral reef fishes. In: Sale PF (ed.), The Ecology of the Fishes on Coral Reefs. Academic Press, San Diego, California, pp. 437-474.

Wood EM. 2001. Collection of Coral Reef Fish for Aquaria: Global Trade, Conservation Issues and Management Strategies. Marine Conservation Society, Herefordshire, UK, 80 pp.

Recibido en noviembre de 2007; aceptado en septiembre de 2008. 